\title{
Diagnostic accuracy of three biomarkers in identifying serious bacterial infections in children younger than 36 months with fever without source
}

\author{
Acuratețea diagnostică a trei biomarkeri în identificarea infecţiilor \\ bacteriene severe la copiii cu vârsta sub 36 luni cu febră fără focar
}

\section{Diana Aniela Moldovan ${ }^{1 *}$, Maria Despina Baghiu ${ }^{2}$, Alina Balas ${ }^{3}$, Emese Rozalia Fabian-Frast ${ }^{4}$, Cristian Boeriu ${ }^{5}$}

1. Tirgu Mures Emergency Clinical County Hospital, University of Medicine and Pharmacy Tirgu Mures; 2. Tirgu Mures Emergency Clinical Hospital, Paediatric Unit, University of Medicine and Pharmacy Tirgu Mures, Department of Paediatrics; 3. Tirgu Mures Emergency Clinical County Hospital, Emergency Department. Address: Gh. Marinescu Street, No. 50, Tirgu Mures, 540136, Romania; 4. Tirgu Mures Emergency Clinical County Hospital, Emergency Department; 5. University of Medicine and Pharmacy Tirgu Mures, Department of Intensive Care and Emergency Medicine Tirgu Mures Emergency Clinical County Hospital, Emergency Department

\begin{abstract}
Objectives: Our study aimed to evaluate and compare the accuracy of C-reactive protein, Procalcitonin and Interleukine-6 in identifying serious bacterial infections (SBI) in children with fever without source.

Methods: 139 children, aged 7 days to 36 months, addressing the Emergency Department from a Romanian university hospital, were prospectively enrolled during 2013. C-reactive protein, Procalcitonin and Interleukin-6 were determined for every patient. SBI diagnosis was based on cultures results and chest radiographs.

Results: 31 patients (22.3\%) had SBI. C-reactive protein [AUC: 0.87 (95\%CI: 0.81-0.92)] and Procalcitonin [AUC: 0.83 (95\%CI: 0.76-0.89)] proved strong prediction value for SBI and performed better than Interleukin-6 [AUC: 0.77 (95\%CI: 0.69-0.84)]. For the group of children with the duration of fever less than 8 hours, Interleukin-6 was the best predictor [AUC: 0.88 (0.76-0.95)].

Conclusions: Both C-reactive protein and Procalcitonin are strong and similar predictors for SBI, and Interleukin-6 might be a better SBI screening tool for children with shorter duration of fever.

Keywords: fever, children, C-reactive protein, Procalcitonin, Interleukin-6

\section{Rezumat}

Obiective: Obiectivele studiului au fost de a evalua şi compara acurateţea Proteinei C-reactive, Procalcitoninei şi Interleukinei-6 in identificarea infecţiilor bacteriene severe (SBI) la copiii cu febră fărră focar.
\end{abstract}

*Corresponding author: Diana Aniela Moldovan, Tirgu Mures Emergency Clinical County Hospital, University of Medicine and Pharmacy Tirgu Mures, Romania, e-mail: diana.moldovan@yahoo.com 
Metodă: 139 copii, cu vârsta între 7 zile şi 36 luni, evaluaţi în Departamentul de Urgenţe a unui spital universitar din Romania, au fost înrolaţi prospectiv în 2013. Proteina C-reactivă, Procalcitonina şi Interleukina-6 au fost determinate pentru fiecare pacient. Diagnosticul de SBI a fost susţinut de rezultatul culturilor şi al radiografilor pulmonare.

Rezultate: 31 pacienţi (22,3\%) au fost diagnosticaţi cu SBI. Proteina C-reactivă [AUC: 0.87 (95\%CI: 0.81 0.92)] şi Procalcitonina [AUC: 0.83 (95\%CI: 0.76-0.89)] s-au dovedit predictori robuşti pentru SBI şi superiori Interleukinei-6. Pentru grupul de copii cu durata febrei sub 8 ore, Interleukina-6 s-a dovedit a fi cel mai bun predictor [AUC: $0.88(0.76-0.95)]$.

Concluzii: Atât Proteina C-reactivă cât şi Procalcitonina sunt predictori robuşti şi similari pentru SBI, iar Interleukina-6 ar putea fi un instrument mai bun pentru screening-ul copiilor cu durata mai scurta a febrei.

Cuvinte cheie: febră, copii, Proteina C-reactivă, Procalcitonina, Interleukina-6

Received: 31 ${ }^{\text {st }}$ March 2015; Accepted: $9^{\text {th }}$ August 2015; Published: $10^{\text {th }}$ September 2015

\section{Introduction}

Approximately $20 \%$ of infants and young children have fever without an apparent source after a complete history and physical examination (1). This represents an ongoing concern for practitioners, as up to $29 \%$ of these children (2) have serious bacterial infections (SBI) such as urinary tract infection (UTI), bacteraemia, pneumonia and meningitis. The identification of children with fever without a source (FWS) who are at risk for SBI through the use of new surrogate biomarkers has been widely researched in the past years.

Among the many biomarkers proposed, C-reactive protein (CRP) (3-5) and Procalcitonin (PCT) (6-8), evaluated either as single biomarkers, in comparison (2,9-13) or in combination (14-17) have gained most interest. Interleukin-6 (IL-6) proved good perspectives on early neonatal sepsis detection $(18,19)$, but so far showed lower performance when compared to CRP or PCT for SBI detection $(2,13)$, and it was asserted that this fact may be related to their different kinetics (2).

The changing epidemiology of SBI in post pneumococcal vaccination era has raised new questions on management strategies regarding children with FWS (12). There is lack of data regarding their applicability on other paediatric populations, like the Romanian children, who are still waiting for pneumococcal vaccination. This study aimed (1) to establish to what extent CRP, PCT and IL-6 can accurately identify SBI in Romanian children seen in a single university hospital and (2) to compare their performance in relation to the time of fever onset.

\section{Materials and Methods}

\section{Design}

We performed a prospective observational study assessing the accuracy of CRP, PCT and IL-6 in identifying children with FWS at risk for SBI. White blood cell levels (WBC) were additionally tested as they are still commonly used in evaluating febrile children.

\section{Patients and Setting}

Our survey was conducted in Tirgu Mures Emergency Clinical County Hospital, Romania. This university hospital has an emergency department (ED) staffed with full-time paediatricians, where the study patients were recruited. Between January 2013 and September 2013 we enrolled all children age 7 days to 36 months who were evaluated for fever and had no signs of infection. We considered febrile children with documented fever $\left(\mathrm{T} \geq 38^{\circ} \mathrm{C}\right)$ either in $\mathrm{ED}$, or at home, when measured with a thermometer. We excluded patients (1) undergoing antibiotic treatment (2) with known congenital or acquired 
immunodeficiencies, (3) with fever lasting more than 7 days. Every child included was examined by a specialist paediatrician who took a complete history and performed a thorough clinical examination. The vital signs, the degree and the duration of fever were recorded for every patient.

All children had blood samples taken in order to measure CRP, PCT, IL-6 and WBC levels. Urine samples were taken for urinalysis. High sensitive-CRP was measured on a PATHFAST rapid analyser (Mitsubishi Chemical Medience Corporation) using a chemiluminescent enzyme immunoassay which provided the result in 17 minutes (results range: $0.05-30 \mathrm{mg} / 1$ ). Whenever a value of $30 \mathrm{mg} / 1$ was present, samples were diluted 1:10 with normal saline, to obtain a quantitative result, as indicated by the manufacturer. PCT was measured by a rapid semiquantitative immunochromatographic test (Brahms PCT-Q: Brahms Diagnostica Berlin) which provided the result in 30 minutes (results range: $<0.5 \mathrm{ng} / \mathrm{ml}$, $\geq 0.5 \mathrm{ng} / \mathrm{ml}, \geq 2 \mathrm{ng} / \mathrm{ml}, \geq 10 \mathrm{ng} / \mathrm{ml}$ ). For IL- 6 measurement, $250 \mu 1$ of plasma were refrigerated at $-70^{\circ} \mathrm{C}$ and the tests were performed after all samples were collected, using the IMMULITE1000 IL-6 chemiluminescent sequential immunometric assay (Siemens); results range: $2-1000 \mathrm{pg} / \mathrm{ml}$. WBC count was determined along with erythrocytes and platelets in blood samples mixed with ethylenediaminetetraacetic acid using an automated cell counter (Sysmex KX-21, Sysmex Corporation, Japan). Urinalysis was determined using a dipstick analyser.

SBI diagnosis was tracked by performing blood, urine, cerebrospinal fluid (CSF) and stool cultures and chest radiographs. Febrile neonates were managed according to current guidelines $(1,20)$. Blood cultures were taken routinely in infants younger than 3 month and in older children if red or amber features, according to National Institute for Health and Care Excellence (NICE) guidelines (20), were present. To perform the blood cultures, three millilitres of blood were taken on BacT/ALERT PF (Biomerieux) pediatric tube. Urine cultures were taken whenever urinalysis was positive for leukocyte esterase and/or nitrites. Urine samples for cultures were collected by catheter whenever feasible or by collector bags when catheterisation was not possible (e.g. phimosis) or parents refused to give permission. Lumbar puncture, CSF analysis and culture were performed whenever suggestive clinical signs were present. Chest radiographs were performed at the discretion of the clinician and interpreted by a radiology specialist.

The diagnosis of SBI was confirmed by the isolation of bacterial pathogens from blood, urine, CSF or stool samples. The diagnosis of UTI was supported in the presence of both leukocyte esterase and/or nitrites and growth of at least 50000 colony forming units, according to American Academy of Pediatrics guidelines (21). Pneumonia was diagnosed if infiltrates were described on chest radiographs.

All children had clinical follow up. When they were admitted, this consisted of review of the medical records. When they were discharged, telephone follow-up was performed at 48 hours and 7 days. The final diagnosis was established after the final follow-up in conjunction with the results of cultures.

\section{Statistical Analysis}

All data was collected in a Microsoft Excel Database. Statistical analysis was performed using the Statistical Package for Social Sciences (SPSS, version 20, Chicago, IL, USA). Data were labelled as nominal or quantitative variables. Nominal variables were characterized by means of frequencies. Quantitative variables were tested for normality of distribution using the Kolmogorov-Smirnov test and were described by mean \pm standard deviation (SD) or median and percentiles $(25 ; 75 \%)$, whenever appropriate. The frequencies of nominal variables 
were compared with a chi-square test. Differences in the mean or median between groups were analysed using the $t$ test or Mann-Whitney test. For the receiver operating characteristic (ROC) curve analysis we used three cut-off levels to test PCT performance. Area under the ROC curve (AUC) was calculated and sensitivity, specificity, positive and negative predictive values were studied for each parameter.

\section{Ethics Approval}

The study protocol was approved by the Ethics Committee of University of Medicine and Pharmacy Tirgu Mures. Informed consent for all children was required and obtained from parents or legal guardians.

\section{Results}

Of 159 children identified with FWS, 139 patients (73 males) were evaluated. We excluded patients with an insufficient amount of serum for PCT and/or IL-6 determination and those for whom informed consent couldn't be obtained.

The median age of patients with SBI was 11 months (interquartile range: 1-32) and 31 patients $(22.3 \%)$ had an SBI: 17 UTI, 11 pneumonia, 1 bacteraemia and UTI, 1 bacterial enterocolitis, 1 sepsis. The general characteristics of patients are reported in Table I.

In the UTI group the most frequently isolated pathogen was E. coli, followed by Proteus mirabilis and Pseudomonas aeruginosa. In the case of bacteraemia and UTI the pathogen isolated was Serratia marcescens. The patient diagnosed with bacterial enterocolitis had a positive stool culture for Yersinia enterocolitica. The patient diagnosed with sepsis according to Levy et al criteria (22) had an initial presentation for fever and admission was advised by the clinician, but parents refused and returned the following day when the child had overt clinical signs of severe sepsis and died several days afterwards.

In the non-SBI group we had three patients diagnosed with non-severe bacterial infections: two otitis media and one maxillary sinusitis. The majority of 108 patients with non-SBI had viral respiratory tract infections and gastroenteritis. We also found two patients with aseptic meningitis, several patients with viral diseases and rash, and several patients with fever without fur-

Table I. General characteristics of the population included in the study

\begin{tabular}{lccc}
\hline Variable & $\mathrm{SBI}(\mathrm{n}=31.22 .3 \%)$ & Non-SBI $(\mathrm{n}=108.77 .7 \%)$ & $\mathrm{p}$ value \\
\hline Age (months) & $11(1-32)$ & $9(0-35)$ & $0.47^{* * *}$ \\
\hline Gender (male), $\mathrm{n}(\%)$ & $13(41.9)$ & $60(55.6)$ & $0.22^{* *}$ \\
\hline Temperature (mean $\pm \mathrm{SD})$ & $38.9 \pm 0.79$ & $38.7 \pm 0.70$ & $0.16^{*}$ \\
\hline Duration of fever (hours), median (IQR) & $24(1-120)$ & $11.5(1-72)$ & $0.01^{* * *}$ \\
\hline WBC (n/mm3), median (IQR) & $14100(4300-37100)$ & $9250(1200-29700)$ & $0.0009^{* * *}$ \\
\hline CRP (mg/l), median (IQR) & $74.8(1.78-300)$ & $4.3(0.03-220)$ & $0.0001^{* * *}$ \\
\hline PCT (ng/ml), n (\%) & & & \\
$<0.5$ & $6(19.4)$ & $94(87.0)$ & $0.0001^{* *}$ \\
$>0.5$ & $12(38.7)$ & $6(5.6)$ & $0.0001^{* *}$ \\
$>2$ & $4(12.9)$ & $3(2.8)$ & $0.0001^{* *}$ \\
$>10$ & $9(29.0)$ & $5(4.6)$ & $0.0001^{* *}$ \\
\hline IL-6 (pg/ml), median (IQR) & $72.4(14.7-1000)$ & $22.2(2-1000)$ & $0.0001^{* * *}$ \\
\hline
\end{tabular}

SD: standard deviation, IQR: interquartile range, WBC: white blood cells, CRP: C-reactive protein, PCT: Procalcitonin, IL-6: Interleukin-6; *Student test, ${ }^{* *}$ chi square test, ${ }^{* * *}$ Mann Whitney test 
ther symptoms and negative cultures, interpreted as mild and transitory viral diseases.

When area under the ROC curve was calculated we found the best result for CRP: 0.87 (95\%CI: 0.81-0.92), closely followed by PCT (0.5 ng/ml): 0.83 (95\%CI: 0.76-0.89). We obtained inferior results for PCT at higher cut-off values: AUC was 0.67 (95\%CI: 0.58-0.75) for PCT $(2 \mathrm{ng} / \mathrm{ml})$ and 0.63 (95\%CI: $0.54-0.71)$ for PCT $(10 \mathrm{ng} / \mathrm{ml})$. We found that IL-6 [AUC 0.77 (95\%CI: 0.69-0.84)] performed better than WBC [AUC 0.69 (95\%CI: 0.61-0.76)], but was inferior to CRP and PCT. The optimal cut-off value for prediction of SBI was $12900 / \mathrm{mm}^{3}$ for WBC, $21 \mathrm{mg} / \mathrm{l}$ for CRP, $0.5 \mathrm{ng} / \mathrm{ml}$ for PCT and $40.6 \mathrm{ng} /$ $\mathrm{ml}$ for IL-6. In Figure 1 we report the comparative laboratory parameters performances.

The sensitivity, specificity, positive and negative predictive values and positive and negative likelihood ratios for different and most common- ly used cut-off levels, as well as for the optimal cut-off levels found, are reported in Table II.

Overall, CRP slightly outperformed PCT, and both were superior SBI predictors compared with IL-6. However, taking into account fever duration, we found different results. In the group with fever lasting less than 12 hours, CRP and PCT performed similarly and both were inferior to IL-6. IL-6 performed increasingly better when utilised for the patient groups with less than 8 and 6 hours of fever, respectively. In Table III we report the differences between CRP, PCT and IL-6 performances in detecting SBI for the groups with shorter duration of fever, using cutoff levels closest to the optimal values found.

\section{Discussion}

Management of FWS in children aged less than 36 months has long been a concern for clinicians. Recently, new biomarkers, especially

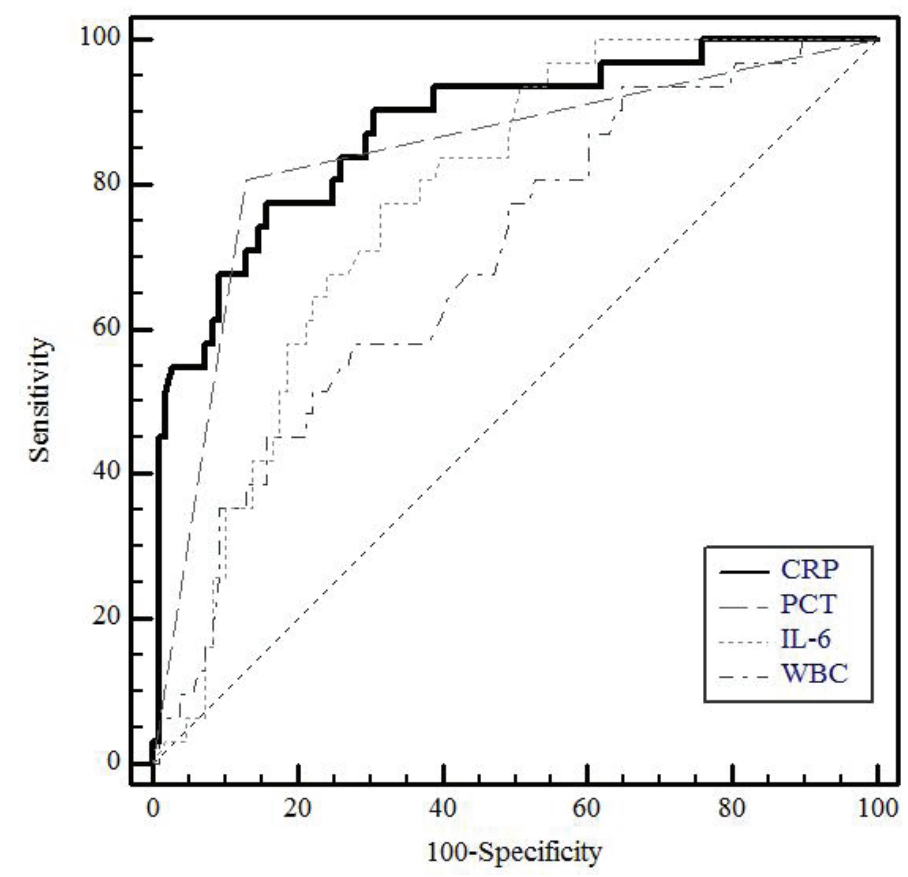

Figure 1. Area under the receiver operating characteristic curves for WBC, CRP, PCT and IL-6 for SBI detection 
Table II. Sensitivity, specificity, PPV, NPV, LR+ and LR- for different cut-off levels for SBI prediction

\begin{tabular}{|c|c|c|c|c|c|c|}
\hline $\begin{array}{l}\text { Parameter } \\
\text { (cut-off level) }\end{array}$ & $\begin{array}{l}\text { Sensitivity } \\
(95 \% \text { CI) }\end{array}$ & $\begin{array}{l}\text { Specificity } \\
\text { (95\% CI) }\end{array}$ & $\begin{array}{c}\text { Positive } \\
\text { predictive } \\
\text { value }(95 \% \mathrm{CI})\end{array}$ & $\begin{array}{c}\text { Negative } \\
\text { predictive value } \\
(95 \% \mathrm{CI})\end{array}$ & $\begin{array}{c}\text { LR+ } \\
(95 \% \text { CI })\end{array}$ & $\begin{array}{c}\text { LR- } \\
(95 \% \mathrm{CI})\end{array}$ \\
\hline \multicolumn{7}{|l|}{ WBC } \\
\hline$\geq 12900 / \mathrm{mm}^{3 *}$ & $58.0(39.1-75.5)$ & $72.2(62.8-80.4)$ & $37.5(24.0-52.6)$ & $85.7(76.8-92.2)$ & $2.0(1.5-2.9)$ & $0.5(0.3-1.0)$ \\
\hline$\geq 15000 / \mathrm{mm}^{3}$ & $45.1(27.3-63.9)$ & $79.6(70.8-86.7)$ & $38.8(23.1-56.5)$ & $83.5(74.8-90.0)$ & $2.2(1.2-3.8)$ & $0.6(0.4-0.9)$ \\
\hline \multicolumn{7}{|l|}{ CRP } \\
\hline$\geq 20 \mathrm{mg} / 1$ & $77.4(58.9-90.3)$ & $82.4(73.9-89.0)$ & $55.8(39.8-70.9)$ & $92.7(85.5-97.0)$ & $4.4(3.6-5.4)$ & $0.2(0.1-0.6)$ \\
\hline$\geq 21 \mathrm{mg} / \mathrm{l}^{*}$ & $77.4(58.9-90.4)$ & $84.2(76.0-90.6)$ & $58.5(42.1-73.7)$ & $92.9(85.8-97.1)$ & $4.9(4.0-6.0)$ & $0.2(0.1-0.6)$ \\
\hline$\geq 40 \mathrm{mg} / \mathrm{l}$ & $61.2(42.1-78.1)$ & $91.6(84.7-96.1)$ & $67.8(47.6-84.0)$ & $89.1(81.8-94.2)$ & $7.3(3.7-14.5)$ & $0.4(0.2-0.6)$ \\
\hline$\geq 80 \mathrm{mg} / 1$ & $48.3(30.2-66.9)$ & $98.1(93.5-99.8)$ & $88.2(62.6-98.7)$ & $86.9(79.5-92.3)$ & $26.1(18.1-37.6)$ & $0.5(0.1-2.2)$ \\
\hline \multicolumn{7}{|l|}{ PCT } \\
\hline$\geq 0.5 \mathrm{ng} / \mathrm{ml}^{*}$ & $80.6(62.5-92.5)$ & $87.0(79.2-92.7)$ & $64.1(47.1-78.7)$ & $94.0(87.3-97.7)$ & $6.2(5.2-7.5)$ & $0.2(0.1-0.4)$ \\
\hline$\geq 2 \mathrm{ng} / \mathrm{ml}$ & $41.9(24.5-60.9)$ & $92.5(85.9-96.7)$ & $61.9(38.4-81.8)$ & $84.7(76.9-90.7)$ & $5.6(3.7-8.6)$ & $0.6(0.3-1.3)$ \\
\hline$\geq 10 \mathrm{ng} / \mathrm{ml}$ & $29.0(14.2-48.0)$ & $97.2(92.1-99.4)$ & $75.0(42.8-94.5)$ & $82.7(75.0-88.8)$ & $10.4(6.0-18.1)$ & $0.7(0.2-2.3)$ \\
\hline \multicolumn{7}{|l|}{ II-6 } \\
\hline$\geq 40.6 \mathrm{pg} / \mathrm{ml}^{*}$ & $77.4(58.9-90.4)$ & $68.5(58.9-77.1)$ & $41.4(28.6-55.1)$ & $91.4(83.0-96.5)$ & $2.4(1.2-4.0)$ & $0.3(0.1-0.7)$ \\
\hline$\geq 50 \mathrm{pg} / \mathrm{ml}$ & $67.7(48.6-83.2)$ & $74.0(64.7-82.0)$ & $42.8(28.8-57.7)$ & $88.8(80.5-94.5)$ & $2.6(1.7-3.9)$ & $0.4(0.2-0.7)$ \\
\hline$\geq 100 \mathrm{pg} / \mathrm{ml}$ & $38.7(21.8-57.8)$ & $87.9(80.3-93.4)$ & $48.0(27.4-69.1)$ & $83.3(75.2-89.7)$ & $3.2(2.1-5.0)$ & $0.7(0.4-1.2)$ \\
\hline
\end{tabular}

*Parameters optimal cut-off level found

WBC: white blood cells, CRP: C-reactive protein, PCT: procalcitonin, IL-6: interleukin-6, LR: likelihood ratio

CRP and PCT have gained increasing interest in the evaluation of febrile children, while WBC has lost importance (23). Although these new biomarkers have been widely researched, there is still a lack of consensus regarding optimal cutoff levels, whether to choose different cut-off levels for ruling in or for ruling out the disease, or which of the biomarkers offer the best performance (24-26). Moreover, even if the biomark- ers' kinetics $(27,28)$ suggests clinicians might use them selectively taking into account fever duration, there is a lack of consistent evidence that this is applicable in clinical practice (29).

In our study group the prevalence of SBI was $22.3 \%$, slightly higher than the median prevalence previously reported (24). The duration of fever and the value of all tested biomarkers were significantly higher in the SBI group. In the non

Table III. Diagnostic performance of CRP, PCT and IL-6 for detection of SBI in relation with the duration of fever

\begin{tabular}{llll}
\hline & $\begin{array}{l}\text { AUC }(\mathbf{9 5} \% \mathrm{CI}) \\
\text { Duration of fever } \\
<\mathbf{6} \text { hours }\end{array}$ & $\begin{array}{l}\text { AUC }(\mathbf{9 5 \%} \% \mathbf{C I} \\
\text { Duration of fever } \\
<\mathbf{8} \text { hours }\end{array}$ & $\begin{array}{l}\text { AUC (95\%CI) } \\
\text { Duration of fever } \\
<\mathbf{1 2} \text { hours }\end{array}$ \\
\hline $\begin{array}{l}\mathrm{CRP} \\
(\geq 20 \mathrm{mg} / \mathrm{l}) *\end{array}$ & $0.72(0.56-0.85)$ & $0.73(0.59-0.84)$ & $0.76(0.64-0.86)$ \\
\hline $\begin{array}{l}\text { PCT } \\
(\geq 0.5 \mathrm{ng} / \mathrm{ml}) *\end{array}$ & $0.81(0.66-0.91)$ & $0.80(0.67-0.89)$ & $0.76(0.64-0.86)$ \\
\hline $\begin{array}{l}\mathrm{IL}-6 \\
(\geq 50 \mathrm{pg} / \mathrm{ml}) *\end{array}$ & $0.88(0.75-0.96)$ & $0.88(0.76-0.95)$ & $0.87(0.76-0.94)$ \\
\hline
\end{tabular}

*Cut-off level, CRP: C-reactive protein, PCT: Procalcitonin, IL-6: Interleukin-6; AUC: area under the receiver operating characteristic curve; CI: confidence interval 
SBI group, the highest CRP value $(220 \mathrm{mg} / \mathrm{l})$ was attributed to a patient with maxillary sinusitis and the highest PCT value $(10 \mathrm{ng} / \mathrm{ml})$ and IL-6 value $(1000 \mathrm{pg} / \mathrm{ml})$ were both attributed to a patient with aseptic meningitis. We reported a death in our SBI group. A 5 months old boy, brought in ED for fever, well-appearing, had no focus of infection and CRP $82 \mathrm{mg} / \mathrm{l}$, PCT $<0.5$ $\mathrm{ng} / \mathrm{ml}$, IL-6 $81.9 \mathrm{pg} / \mathrm{ml}$, negative urinalysis and chest radiograph. Parents refused admission. Despite oral antibiotic treatment, the infant was brought the next day with overt signs of clinical sepsis and died several days after in the paediatric intensive care unit. The necropsy report described pulmonary infiltrates in both lungs and although cultures were negative, the case was interpreted as sepsis, probably with pulmonary onset.

While some studies found similar performances for detecting SBI for WBC and CRP (30) or for WBC, CRP and PCT (12), the majority demonstrated better predictive values for CRP and/or PCT compared with WBC $(2,3,6,9-$ $11,13,14,32)$. Recently, De et al (23) found in a large $(n=3893)$ cohort of children that WBC [AUC 0.65 (95\% CI: 0.63- 0.67)] was not accurate enough to be used as triage test for febrile children with suspected SBI. Our findings support this evidence, with an AUC for WBC of 0.69 (95\% CI: 0.61-0.76)] for SBI prediction.

A systematic review assessing the value of laboratory tests for identifying SBI, published by Van den Bruel et al, argued that current data suggested that the tests providing the best value for predicting SBI were CRP and PCT, with no evidence that one performed better than the other (24). However, their reported accuracy varies. For CRP we have found reported LR+ values ranging from 2,3 (29) to 5,4 (11) and LR- values ranging from 0,19 (15) to 0,53 (29). Moreover, the area under the ROC curve for CRP as SBI predictor, reported by Pulliam et al (3) was 0.90 (95\%CI: 0.80-1.00) and only 0.77 (95\%CI: 0.69-
$0.85)$ by Nijman et al (29) and also 0.77 (95\%CI: $0.73-0.80$ ) by Bressan et al (17). Several other reports $(8,10,11,15,31)$ are situated between these limits. With an AUC for CRP of 0.87 (95\%CI: 0.81-0.92), similar as reported by Galetto-Lacour et al (9), our findings are situated on the higher range of data previously reported. We found the best cut-off level for CRP of $21 \mathrm{mg} / 1$. While some studies found as well lower cut-off levels $(11,12,32)$, most of them determined it to be at least $40 \mathrm{mg} / \mathrm{l}$ or higher $(2,3,9,10,30,31)$. However, it was asserted (24) that to reduce the risk of SBI to $5 \%$, a cut-off level below $20 \mathrm{mg} / 1$ should be used for CRP in order to safely discharge children for observation at home. Nevertheless, as the cut-off level increases, the probability of SBI rises. Using CRP added value to the clinical signs Nijman et al (25) established, through a promising clinical prediction model, risk thresholds for all children with fever.

There is a similar pattern for PCT, its reported predictive values for SBI varying from a LR+ of 1.75 (14) to 5.15 (31) and a LR- of 0.25 (14) to 0.51 (29). There is also variability for the ROC curves, with AUC ranging from 0.88 reported by Galetto-Lacour et al (9) and 0.87 (95\%CI: 0.85-0.89) reported by Luaces-Cubells et al (31) to 0.73 (95\% CI: 0.69-0.77) reported by Bressan et al (17). We found an AUC for PCT of 0.83 (95\%CI: $0.76-0.89$ ) for the $0.5 \mathrm{ng} / \mathrm{ml}$ cut-off level, which was also the optimal level found. While some studies found lower cut-off levels $(6,7,12)$, permitting a more-limited approach, most of the studies reported a cut-off of $0.5 \mathrm{ng} /$ $\mathrm{ml}$ or higher (2,9-11,14,15,31-34). Even if only modestly, CRP outperformed PCT for prediction of SBI in our study, which agrees with the findings of several other studies $(10-12,15,17,29)$.

Gendrel et al (13) found that IL-6 was inferior to CRP and PCT in predicting bacterial infection in febrile children. Galetto-Lacour et al $(2,9)$ also found that IL-6 (AUC 0.77) was inferior to CRP and PCT for SBI prediction. However, 
they also reported that higher concentrations of IL-6 were found in the group of children with shorter duration of fever. Overall, we also found IL-6 [AUC of 0.77 (95\%CI: 0.69-0.84)] to be inferior to CRP and PCT. By contrast, when tested in the groups of children with shorter duration of fever, IL-6 was the best predictor for SBI. PCT was superior to CRP in the group with less than 6 and 8 hours of fever. Our results support what has been reported, namely, that IL-6 levels peak earliest after an infectious stimulus, 3 hours earlier than PCT levels, while CRP levels increase latest in the course of disease (27).

Our study has several limitations. First, being a single centre study, a relatively small cohort of children was included. Secondly, blood cultures were not available for every patient, potentially limiting the diagnosis of occult bacteraemia. This possible bias, however, appears minimal, given the fact that the prevalence of occult bacteraemia in an only Haemophilus influenzae type $\mathrm{b}$ and not pneumocoсcus vaccinated population, like our group of study, is less than $2 \%$ (35). Thirdly, the potential for inappropriately diagnosing UTI exists, as not all urine cultures were obtained via catheter nor did we assess children using 99m-T dimercaptosuccinic acid scintigraphy. Nevertheless, the percentage of UTI found in our population is similar with previously published data $(2,5,6,9,12)$.

Despite these limitations we believe our study supplies missing data from the central-eastern-European region regarding the evaluation of SBI using biomarkers, as the overwhelming majority of previously published studies were performed at western European, US and Canadian centres.

In our study group, both C-reactive protein and Procalcitonin are strong and similar predictors for SBI, and Interleukin-6 might be a better SBI screening tool for children with shorter duration of fever.

\section{Acknowledgments}

We acknowledge Minodora Dobreanu, Professor of Laboratory Medicine from University of Medicine and Pharmacy Tirgu Mures for scientific advice. We also acknowledge the ED nurses and Laboratory staff from Tirgu Mures Emergency Clinical County Hospital for helping with data collection and for providing sample analysis for IL-6, respectively.
Abbreviations:
CRP: C-reactive protein
CSF: Cerebrospinal fluid
IL-6: Interleukin-6
PCT: Procalcitonin
SBI: Serious Bacterial Infection(s)
UTI: Urinary Tract Infection(s)
WBC: White Blood Cell

\section{References}

1. Baraff LJ. Management of infants and young children with fever without source. Pediatr Ann. 2008;37(10):673-9. DOI: $\quad$ 10.3928/0090448120081001-01

2. Galetto Lacour A, Zamora SA, Gervaix A. Bedside procalcitonin and C-reactive protein tests in children with fever without localizing signs of infection seen in a referral center. Pediatrics. 2003;112(5):1054-60. DOI: 10.1542/peds.112.5.1054

3. Pulliam PN, Attia MW, Cronan KM. C-reactive protein in febrile children 1 to 36 months of age with clinically undetectable serious bacterial infections. Pediatrics. 2001;108(6):1275-9. DOI: 10.1542/peds.108.6.1275

4. Pratt A, Attia MW. Duration of fever and markers of serious bacterial infections in young febrile children. Pediatr Int. 2007;49(1):31-5. DOI: 10.1111/j.1442200X.2007.02316.x

5. Hsiao AL, Chen L, Baker MD. Incidence and predictors of serious bacterial infections among 57-to180-daysold infants. Pediatrics. 2006;117(5):1695-701. DOI: 10.1542/peds.2005-1673

6. Maniaci V, Dauber A, Weiss S, Becker KL, Bachur R. Procalcitonin in young febrile infants for the de- 
tectin of serious bacterial infections. Pediatrics. 2008;122(4):701-10. DOI: 10.1542/peds.2007-3503

7. Woelker JU, Sinha M, Christopher NC, Powell KR. Serum procalcitonin concentration in the evaluation of febrile infants 2 to 60 days of age. Pediatr Emerg Care. 2012;28(5):410-5. DOI: 10.1097/PEC. 0b013e318252c474

8. Mahajan P, Grzybrowski M, Chen X, Kannikeswaran N, Stanley R, Singal B, et al. Procalcitonin as a marker of serious bacterial infections in febrile children younger than 3 years old. Acad Emerg Med. 2014;21(2):1719. DOI: 10.1111 /acem. 12316

9. Galetto Lacour A, Gervaix A, Zamora SA, Vadas L, Roux Lombard P, Dayer JM, et al. Procalcitonin, IL6, IL-8, IL-1 receptor antagonist and C-reactive protein as identificators of serious bacterial infections in children with fever without localising signs. Eur J Pediatr. 2001;160:95-100. DOI: 10.1007/s004310000681

10. Andreola B, Bressan S, Callegaro S, Liverani A, Plebani M, Da Dalt L. Procalcitonin and C-reactive protein as diagnostic markers of severe bacterial infections in febrile infants and children in the emergency department. Pediatr Infect Dis J. 2007;26:672-7. DOI: 10.1097/INF.0b013e31806215e3

11. Olaciregui I, Hernandez U, Munoz JA, Emparanza JI, Landa JJ. Markers that predict serious bacterial infection in infants under 3 months of age presenting with fever of unknown origin. Arch Dis Child. 2009 94:5015. DOI: 10.1136/adc.2008.146530

12. Manzano S, Bailey B, Gervaix A, Cousineau J, Delvin E, Girodias JB. Markers for bacterial infection in children with fever without source. Arch Dis Child. 2011;96:440-6. DOI: 10.1136/adc.2010.203760

13. Gendrel D, Raymond J, Coste J Moulin F, Lorrot M, Guérin S, et al. Comparison of procalcitonin with C-reactive protein, interleukine- 6 and interpheron-alpha for differentiation of bacterial vs. viral infections. Pediatr Infect Dis J. 1999;18:875-81. DOI: 10.1097/00006454199910000-00008

14. Thayyil S, Shenoy M, Hamaluba M, Gupta A, Frater J, Verber IG. Is procalcitonin useful in early diagnosis of serious bacterial infections in children? Acta Pediatrica. 2005;94:155-8. DOI: 10.1080/08035250410025140

15. Galetto-Lacour A, Zamora SA, Gervaix A. A score identifying serious bacterial infections in children with fever without source. Pediatr Infect Dis J. 2008;27:6546. DOI: 10.1097/INF.0b013e318168d2b4
16. Galetto-Lacour A, Zamora SA, Andreola B, Bressan S, Lacroix L, Da Dalt L et al. Validation of a laboratory index score for the identification of severe bacterial infection in children with fever without source. Arch Dis Child. 2010;95:968-73. DOI: 10.1136/adc.2009.176800

17. Bressan S, Gomez B, Mintegi S, Da Dalt L, Blazquez D, Olaciregui I, et al. Diagnostic performance of the Lab-score in predicting severe and invasive bacterial infections in well-appearing young febrile infants. Pediatr Infect Dis J. 2012;31:1239-44. DOI: 10.1097/ INF.0b013e318266a9aa

18. Buck C, Bundschu J, Gallati H, Bartmann P, Pohlandt F. Interleukin-6: a sensitive parameter for the early diagnosis of neonatal bacterial infection. Pediatrics. 1994;93:54-8.

19. Küster H, Weiss M, Willeitner AE, Detlefsen S, Jeremias I, Zbojan J, et al. Interleukin-1 receptor antagonist and interleukin-6 for early diagnosis of neonatal sepsis 2 days before clinical manifestation. Lancet. 1998;352(9136):1271-7. DOI: 10.1016/S01406736(98)08148-3

20. NICE Clinical Guideline 47. Feverish illness in children: assessment and initial management in children younger than 5 years. National Collaborating Center for Women's and Child Health; 2007.

21. Subcommittee on Urinary Tract Infection, Steering Committee on Quality Improvement and Management, Roberts KB. Urinary tract infection: clinical practice guideline for the diagnosis and management of initial UTI in febrile infants and children 2 to 24 months. Pediatrics. 2011;128(3):595-610. DOI: 10.1542/peds.20111330

22. Levy MM, Fink MP, Marshall JC, Abraham E, Angus D, Cook D, et al. $2001 \mathrm{SCCM} / \mathrm{ESICM} / \mathrm{ACCP} /$ ATS/SIS International Sepsis Definitions Conference. Crit Care Med. 2003;31:1250-6. DOI: 10.1097/01. CCM.0000050454.01978.3B

23. De S, Williams GJ, Hayen A, McCaskill M, Isaacs D, Craig JC. Value of white cell count in predicting serious bacterial infection in febrile children under 5 years of age. Arch Dis Child. 2014;99(6):493-9. DOI: 10.1136/ archdischild-2013-304754

24. Van den Bruel A, Thompson MJ, Haj-Hassan T, Stevens $\mathrm{R}$, Moll $\mathrm{H}$, Lakhanpaul $\mathrm{M}$, et al. Diagnostic value of laboratory tests in identifying serious infections in febrile children: systematic review. BMJ. 2011;342:d3082. DOI: 10.1136/bmj.d3082 
25. Nijman RG, Vergouwe $Y$, Thompson M, van Veen $M$, van Meurs AH, van der Lei J, et al. Clinical prediction model to aid emergency doctors managing febrile children at risk of serious bacterial infections: diagnostic study. BMJ. 2013;346:f1706.

26. Chiesa C, Natale F, Pascone R, Osborn JF, Pacifico L, Bonci $\mathrm{E}$, et al. $\mathrm{C}$ reactive protein and procalcitonin: reference intervals for preterm and term newborns during the early neonatal period. Clin Chim Acta. 2011;412(1112):1053-9. DOI: 10.1016/j.cca.2011.02.020

27. Dandona P, Nix D, Wilson MF, Aljada A, Love J, Assicot $\mathrm{M}$, et al. Procalcitonin increase after endotoxin injection in normal subjects. J Clin Endocrinol Metab. 1994;79:1605-8. DOI: 10.1210/jc.79.6.1605 DOI: 10.1210/jcem.79.6.7989463

28. Gendrel D, Bohuon C. Procalcitonin as a marker of bacterial infection. Pediatr Infect Dis J. 2000;19(8):67988. DOI: 10.1097/00006454-200008000-00001

29. Nijman RG, Moll HA, Smit FJ, Gervaix A, Weerkamp F, Vergouwe Y, et al. C-reactive Protein, Procalcitonin and the Lab-Score for Detecting Serious Bacterial Infections in Febrile Children at the Emergency Department: A Prospective Observational Study. Pediatr Infect Dis J. 2014;33:273-9. DOI: 10.1097/INF.0000000000000466

30. Issacman DJ, Burke BL. Utility of the serum C-reactive protein for detection of occult bacterial infection in children. Arch Pediatr Adolesc Med. 2002;156 (9):9059. DOI: 10.1001/archpedi.156.9.905

31. Luaces-Cubels C, Mintegi S, Garcia-Garcia JJ, Astob- iza E, Garrido-Romero R, Velasco-Rodríguez J, et al. Procalcitonin to detect invasive bacterial infections in non-toxic-appearing infants with fever without apparent source in the emergency department. Pediatr Infect Dis J. 2012;31(6):645-7. DOI: 10.1097/INF.0b013e31824dacf4

32. Fernandez Lopez A, Luaces-Cubels C, Garcia-Garcia JJ, Fernández Pou J; Spanish Society of Pediatric Emergencies. Procalcitonin in pediatric emergency departments for the early diagnosis of invasive bacterial infections in infants: results of a multicenter study and utility of a rapid qualitative test for this marker. Peiatr Infect Dis J. 2003;22:895-903. DOI: 10.1097/01. inf.0000091360.11784.21

33. Gomez B, Bressan S, Mintegi S, Da Dalt L, Blazquez D, Olaciregui I, et al. Diagnostic value of procalcitonin in well-appearing young febrile infants. Pediatrics. 2012;130:815-22. DOI: 10.1542/peds.2011-3575

34. Laham JL, Breheny PJ, Gardner BM, Bada H. Procalcitonin to predict bacterial coinfection in infants with acute bronchiolitis: a preliminary analysis. Pediatr Emerg Care. 2014;3(1):11-5. DOI: 10.1097/ PEC.0000000000000026

35. Alpern ER, Alessandrini EA, Bell LM, Shaw KN, McGowan KL. Occult bacteremia from a pediatric emergency department: current prevalence, time to detection, and outcome. Pediatrics. 2000;106(3):505-11. DOI: $10.1542 /$ peds.106.3.505 